\title{
CHRISTIANS IN THE GLOBAL GREENHOUSE ${ }^{1}$
}

\author{
Donald A. Hay
}

\section{Introduction}

The inhabitants of planet Earth are quietly conducting a gigantic environmental experiment. So vast and sweeping will be the consequences that, were it brought before any responsible council for approval, it would be firmly rejected. Yet it goes on with little interference from any jurisdiction or nation. The experiment in question is the release of $\mathrm{CO}_{2}$ and other so-called 'greenhouse gases' to the atmosphere. $^{2}$

This quotation from Broecker typifies the increasing alarm being expressed by environmental and atmospheric scientists over the 'greenhouse effect'. Put simply, this effect arises from the activities of the human race in releasing into the atmosphere quantities of carbon dioxide (by burning fossil fuels) and of other trace gases such as chlorofluorocarbons, methane and nitrogen oxides (from activities as apparently harmless as using aerósol sprays, or driving cars). These greenhouse gases have no substantial effect on the incoming radiation from the sun, which heats the earth's surface: but are very effective in preventing the escape from the atmosphere of the infrared radiation from the warmed surface of the earth. As the greenhouse gases accumulate, so the warming effect becomes more and more pronounced. Furthermore, man's activities have also interfered, in a substantial way, with the natural processes by which carbon dioxide and other trace gases are removed from the atmosphere: the destruction of tropical rain forests is a very significant example. The precise environmental impact of

${ }^{1}$ This was 1989 Tyndale Fellowship Annual Lecture in Ethics. The assistance of Kathryn Davies in the preparation of this paper is gratefully acknowledged. John Houghton and Peter Jensen provided critical comments on an earlier version. Ernest Lucas helped me to clarify some issues of Biblical interpretation in section III.

${ }^{2}$ W.S. Broecker, 'Unpleasant surprises in the greenhouse?' Nature 328 (9 July 1987) 123. 
these activities is far from certain, ${ }^{3}$ mainly because the interactions between the atmosphere, the oceans and the land in determining world climates and biological activities are so complex. Some of the scenarios envisaged read more like science fiction: 'The world is warming. Climatic zones are shifting. Glaciers are melting. Sea level is rising.$^{4}$ But the same authors go on to state:

These are not hypothetical events from a science-fiction movie: these changes are already taking place, and we expect them to accelerate over the next years as the amounts of carbon dioxide, methane and other trace gases accumulating in the atmosphere through human activities increase.

The purpose of this paper is to ask whether Christians have a distinctive viewpoint on these matters. In section II it is noted that the issues raised go far beyond scientific analysis. If steps are to be taken to counter the greenhouse effect, then there are likely to be profound consequences for economic life. Major ethical issues then arise: on what basis are decisions to be reached between the claims of the present and future generations, how is the conflict to be handled between individual freedom and the possibly draconian restrictions on that freedom which will be necessary to combat the greenhouse effect, and how far should our ethics assign value to the material order in itself, and not just as the environment within which the human drama (presumably a tragedy) is played out? Moreover Christians need to recognise that influential analyses of the environmental crisis have pointed an accusing finger at Christian doctrines of the created order, and the role of the human race within that order, as the cultural causes of our contemporary problems. Section III, therefore, reviews the Biblical roots of these doctrines to see whether these accusations can be sustained, and to derive ethical principles to guide our subsequent analysis. Section IV, rehearses the scientific evidence for the greenhouse effect in more detail. In section V, an economic analysis of the issues is given. A key

${ }^{3}$ S.H. Schneider, 'The greenhouse effect: science and policy', Science, 243 (10 February 1989) 771-81.

${ }^{4}$ R.A. Houghton and G.M. Woodwell, 'Global climatic change', Scientific American 260.4 (April 1989) 18. 
question is how we have got into our present situation. The solutions proposed are then critically analysed in the light of Christian ethical principles. Section VI concludes the paper by raising a number of unresolved issues. This description of contents sets a formidable agenda for a short paper. Unfortunately, any analysis has to span ethical, scientific and economic aspects if progress is to be made in understanding.

\section{Thinking about the environmental crisis}

There are two reasons why Christians should be alert to the issues raised by the environmental crisis. The first is that Christianity has itself been blamed as the cultural cause for what has happened. The second is that there is a lively current debate on environmental ethics to which it is imperative that Christians should contribute: we need to evaluate the options.

The attack on Christianity as a proximate cause of the environmental crisis was first articulated in the late 1960s. The first charge goes back to the interpretation of Genesis 1:28 with its exhortation of mankind to 'have dominion' over the created order and to 'subdue the earth'. This passage, it is alleged, sets mankind apart and above the creation, so that nature is seen as no more than a resource for exploitation to satisfy human aspirations. McHarg made the point forcefully. 5

the Biblical creation story of the first Chapter of Genesis, the source of the most generally accepted description of man's role and powers...in its insistence upon dominion and subjugation of nature encourages the most exploitative and destructive instincts in man, rather than those that are deferential and creative. Indeed if one seeks licence for those who would increase radioactivity..., employ poisons without restraint, or give consent to the bulldozer mentality, there could be no better injunction than this text.

A rather more thoughtful attack was made by Lynn White Jr. in a paper entitled "The Historical Roots of an

5. McHarg, Design with Nature, (Doubleday, New York, 1969) 26. 
Ecological Crisis'. ${ }^{6}$ The charge is that 'Christianity...insisted that it is God's will that man exploit nature for his proper ends', so that 'Christianity bears a huge burden of guilt'. The doctrine of mankind's dominance over nature is seen as underpinning the growth of modern science, and as blessing the development of modern technology.

These attacks have generated a huge literature in response. ${ }^{7}$ With respect to the implications of Genesis 1, Barr 8 has challenged the interpretation of these passages that 'dominion' implies exploitation. Furthermore, he points out that the Israelites were not noted in the ancient Near East for their technological advances, while cultures that had naturereligions made remarkable technological advances of which the pyramids of Egypt are the most notable examples. The use of Genesis 1:28 as a 'proof text' to justify the exploitation of nature is inconsistent with the true theology of the natural order of the Old Testament. A similar point can be made with respect to Christian theology. The work of Santmir ${ }^{9}$ and Attfield ${ }^{10}$ indicates that there have been other strands of response to nature in Christian theology, many of which have maintained a belief that humanity is a steward of the created order, charged with a responsibility to conserve, maintain and care for it. At best, the case against Christianity must be regarded as unproven: other suspects should be considered, including the impact of Enlightenment thought. ${ }^{11}$

The second reason for stating a Christian position in environmental issues is the need to contribute to the current debate. Two strands of thought can be distinguished. One arises from the application of rationalistic or philosophical ethics: the other is a natural ethic based on an understanding of the biosphere as an organism with its own values. Philosophical

${ }^{6} \mathrm{~L}$. White Jr., 'The historical roots of an ecological crisis', Science 155 , (10 March 1967) 1204-7.

7I. Barbour (ed.), Westerm Man and Environmental Ethics, (Addison-Wesley, Reading, Mass., 1973).

8. Barr, Man and nature-the ecological controversy and the Old Testament', BJRL 55 (1972) 9-32.

${ }^{9}$ H.P. Santmire, The Travail of Nature, (Fortress Press, Philadelphia, 1985).

${ }^{10} \mathrm{R}$. Attfield, The Ethics of Enoironmental Concern (Blackwell, Oxford, 1983).

${ }^{11}$ W. Granberg-Michelson, $A$ Wordly Spirituality: The Call to Take Care of the Earth (Harper and Row, San Francisco, 1984) Ch. 3. 
ethical positions have been conveniently summarised by Shrader-Frechette. ${ }^{12}$ She identifies three questions for discussion: the ethics of distribution, the conflict between individual autonomy and group welfare, and the possibility of conducting environmental ethics in an 'ecocentric' rather than an anthropocentric framework. The answers to these questions will generally vary depending on one's ethical stance. Thus a utilitarian will be prepared to accept inequality, and the consequent devaluing of the rights of minorities, in the search for a maximum social welfare. A libertarian will probably take a diametrically opposite view on distributive questions and individual rights. Interestingly, Shrader-Frechette accuses libertarians of failing to appreciate their philosophical roots. Thus Locke was only prepared to sanction the annexation of land to oneself as private property, if 'as much and as good is left in common for others'. This is not likely to be an important proviso in an uncrowded world, but is very significant when global scarcities or problems are under consideration. ${ }^{13} \mathrm{~A}$ further issue is how far ethical theory can assign values or even rights to the created order. An extension to all sentient beings (animals for example) can be easily accommodated within a utilitarian framework, and some have argued (Singer) ${ }^{14}$ that animals have significant rights on a par with human beings.

The development of a natural ethic is an alternative approach. The concept of Gaia has been proposed and elaborated by a highly independent British ecologist, James Lovelock, ${ }^{15}$ and by an American biologist, Lyn Margulis. It is variously described as a 'hypothesis' and as an 'inspirational idea'. Lovelock invites us to compare the following statements: Life exists only because material conditions on earth happen to be just right for existence' and 'Life defines the material con-

\footnotetext{
${ }^{12} \mathrm{~K}$. Shrader-Frechette, 'Environmental ethics and global imperatives' in $R$. Repetto (ed.) The Global Possible (Yale University Press, 1985) 97-127.

${ }^{13}$ For further analysis of utilitarian and rights-based ethical approaches see D.A. Hay, Economics Today: A Christian Critique (Leicester, Apollos, 1989) ch. 3. ${ }^{14} \mathrm{P}$. Singer, In Defence of Animals (Blackwell, Oxford, 1985).

15J. Lovelock, Gaia (OUP, 1970). See also J. Lovelock and S. Epton, The quest for Gaia' in J. Gribbin (ed.) The Breathing Planet (Basil Blackwell and New Scientist, Oxford 1986) (paper first published in New Scientist, 6 February 1975).
} 
ditions needed for its survival and makes sure that they stay there'.

The first statement is the conventional wisdom about how life on earth is maintained, in the face of an otherwise apparently lifeless universe. The alternative wisdom in the second statement encapsulates the Gaia hypothesis. Living matter is not passive in the face of threats to its existence:

Prima facie the atmosphere looked like a contrivance put together cooperatively by the totality of living systems to carry out certain necessary central functions...The system seemed to exhibit the behaviour of a single organism, even a living creature. ${ }^{16}$

We will return to the scientific details in section IV below. The question we have to address here is whether this is science or ethics. The scientific community initially refused to accept it as science: but there is now cautious acceptance that it constitutes an alternative paradigm for the understanding of the biosphere. It is a framework of study rather than a single 'hypothesis'. On the other hand, Gaia is the Greek for the earth goddess, and Lovelock can write: 'Let us make peace with Gaia on her terms, and return to peaceful coexistence with our fellow creatures'. ${ }^{17}$ Despite Lovelock's insistence that he is only speaking metaphorically, it is evident that this could easily be construed as a natural metaphysic, giving a softer edge to 'hard' science and technology. It is therefore likely to form the basis for constructing a natural environmental ethic, with long term survival of the biosphere (and the human race, hopefully!) as an ethical objective.

\section{An outline of a Biblical ethic for the environment}

This section reviews some of the Biblical materials relevant to our theme. ${ }^{18}$ Our starting point is the Biblical tradition. The authority of Scripture is accepted, but it is recognised that in practice the Bible is interpreted within a framework of Biblical theology, which is provisional in relating the elements of the Biblical materials to each other. The assumption

${ }^{16}$ Lovelock and Epton, op. cit. 5.

${ }^{17}$ Lovelock and Epton, op. cit. 9.

${ }^{18}$ The approach will be that outlined in Hay, op. cit. 'Postscript', 309-13. 
is that the Biblical witness, in all its diversity, is a consistent and faithful record of the revelation of a consistent God. No apology is offered therefore for our proposal to seek for derivative principles which sum up Biblical teaching in the area under consideration. A systematic formulation of the ethical principles embedded in the Biblical materials is attempted. Some of these principles will be self evident, while others need to be teased out. The process of deriving the principles cannot be strictly deductive in the logical sense. It is inductive, in the general rather than the formal sense of the word. So the principles are provisional, and subject to constant re-evaluation in the light of the Biblical material. The task of doing ethics Christianly is never closed and completed.

The derivative principles are then used in our approach to problems in the world. Three steps in application may be distinguished. The first is epistemological: the derivative principles provide a framework for deciding what issues are important for our understanding of reality, and therefore what facts we need to consider. The second step is ethical: the 'gap' is identified between the derivative principles and reality. The gap will exist because of the fallenness of mankind, and its pervasive influence on all our endeavours and institutions. The final step is prescriptive: how does one respond to the gap between principles and reality in each concrete circumstance? It is noted that the first best is not attainable, since Eden cannot be re-created. What is being looked for is a second best, which captures the best that is practicable in a fallen world, including a judgement about what is politically and socially feasible given our circumstances. How much we try to achieve will also depend on the urgency and seriousness of the problems that are being addressed.

It is noted that the stages outlined above are intended to indicate the priority that we give to the Biblical tradition in the structure of our ethical thinking. That tradition is authoritative, provided that we interpret it right. It controls the derivative principles and hence our perception of reality. But the process of thinking is not likely to be so tidy. Interaction between tradition, principles and reality is normal: reality confronts us with new problems for which our derivative principles 
are inadequate guides, so we look back to the Biblical tradition to guide us.

The review of Biblical materials cannot be exhaustive. ${ }^{19}$ The focus is on two major themes: the theme of creation, and the theme of fall, judgement and the Noachic covenant. On creation, our focus will be Genesis 1:26-31, and 2:15. However it is important to note the context of these passages. The message, like that of Psalm 104, is that the creation is valued by God in and for itself, and that God is to be praised for his handiwork. Hence the recurring refrain: 'It was very good'. Mankind is created from the dust, a part of the created order, and not a separate creation. The key question we have to address is how mankind relates to that order. There are three elements.

The first is the statement in 1:26 that man is created in the 'image of God'. This phrase has invited a wide debate on interpretation. However the most helpful interpretation for our purposes is that provided by von Rad. ${ }^{20}$ He points to the practice of Near Eastern kings of erecting images of themselves in lands that they had conquered or claimed possession of. These images staked a claim to ownership and sovereignty. Hence man in God's image should be interpreted as indicating God's claim to his creation. Man is God's vicegerent or representative to maintain God's claim, and is given dominion to protect and preserve God's territory.

In Genesis $1: 28$, the human race is enjoined to Be fruitful and multiply, and fill the earth and subdue it: and have dominion over the fish of the sea and over the birds of the air and over every living thing that moves upon the earth'. The word 'subdue' has generated a good deal of heart searching among environmentally minded Christians. The Hebrew root is a harsh word, which could be interpreted to permit exploitation of the natural environment. However, it is worth noting that the word is applied only to the ground, and in that context it could mean no more than to take under control for cultivation. That would tie in nicely with the exhortation to be fruitful:

\footnotetext{
${ }^{19}$ For a fuller analysis see: W. Granberg-Michelson op. cit., L. Wilkinson (ed.) Earthkeeping: Christian Stewardship of Natural Resources (Eerdmans, 1980) Part II, and K. Innes Caring for the Earth, Grove Ethical Studies 66, (Bramcote, Nottingham, 1987).

${ }^{20} \mathrm{G}$. von Rad, Genesis (London, SCM, 1961).
} 
cultivation is the means to fruitfulness. Note too that there is no mention of animals as food. Finally, any interpretation of this verse has to take account of the fact that it is describing a situation before the Fall. The apparent harshness of 'dominion' and 'subdue' is tempered by a perfect relationship between man and God. It is unthinkable, in that context, that man should exercise dominion, on God's behalf, by destroying his created order which is very good.

This gentler interpretation is backed up by consideration of Genesis 2:15. In this version of the Creation story, the man is put in the Garden to till it and keep it. The idea is that of cooperating with, and serving, the natural order. The naming of the animals which follows implies not only authority, but also relationship. Giving the creatures names, in Hebrew thought, is to recognise their independent and valued status.

This idyllic picture is grievously altered by the Fall, and by the subsequent events. In Genesis 3:5, Bonhoeffer notes the transition from mankind in the image of God to '...you will be like God, learning good and evil'. ${ }^{21}$ The first act of defiant rebellion is. to claim the right to the fruit of a tree which God had specifically forbidden. Adam and Eve are claiming a right of personal possession to use the created order as they please. They are no longer God's vicegerents. The consequences are spelt out in Genesis 3:17-19. The Fall infects all relationships. Wright has used the helpful diagrammatic device of a triangle with God at one vertex, and man and the created order at the other two vertices. ${ }^{22}$ The effect of the Fall is to alienate man not only from God, but also from a proper relationship with the created order. The ground is cursed, and no longer fruitful. The full tragedy of the new situation is emphasised in the story of Cain. Cain is a tiller of the soil, yet he is destined to be a wanderer in the earth (4:12). Wandering and tilling the soil are, of course, incompatible.

In the covenant with Noah, God takes the initiative to limit the effects of this disastrous situation. In 8.21, after

\footnotetext{
${ }^{21} \mathrm{D}$. Bonhoeffer, Creation and Fall: $A$ Theological Interpretation of Genesis 1-3 (London, SCM, 1959).

${ }^{22}$ C.J.H. Wright, Living as the People of God, (Leicester, IVP, 1983).
} 
Noah emerges from the Ark, God promises that the destruction wrought by the Flood will not be repeated, and the regular procession of the seasons is reaffirmed in 8:22 as an echo of the Creation narrative of Genesis 1 . The corollary is that the promises of 1:28ff. are repeated in 9:1-7, but in a form modified to take account of the disruption caused by the Fall. For example, the injunctions of 1:28 to have dominion and subdue, are replaced in 9:2 by a statement of the fact of man's dominion over the created order, a dominion which leaves the living creatures in 'fear and dread' of man. (That man continues to exercise dominion is affirmed by Psalm 8 , and by the quotation from Psalm 8 in Hebrews 2). Animals are now made available for food, but their blood, as a symbol of their life, is to be respected. The implication is that the role of the human race in relation to the created order is unalterable, but that God is well aware of the destructive propensities of fallen man. So, in 9:817 , God makes a covenant with all living things. Just as the animals were included in the Ark, so too the covenant extends to them, as much as to Noah and his family. The rainbow is the sign of God's gracious initiative, and it does not apparently depend on man's response.

We are now in a position to summarise these Biblical themes in three derivative principles:

1. The creation is good. The curse pronounced after the Fall affects the human race in relation to the created order. In the covenant with Noah, God includes all the living creatures and reaffirms the cycle of the seasons, to emphasize his continuing commitment to his creation.

2. Man is God's vicegerent with a mandate ('dominion') to care for and to sustain, the creation. The danger is that a fallen humanity will usurp God's ultimate ownership of the created order and exploit it. That danger needs to be vigorously resisted.

3. Man is enjoined to subdue the earth and to be fruitful: we may use the resources of creation to provide for our existence, but we must not destroy or waste it. Our proper role is that of steward: caring for and preserving the created order, and only taking from it what is necessary to sustain a fruitful life.

These principles will inform our thinking as we turn in the next two sections to a description of the scientific and eco- 
nomic issues involved in the greenhouse effect. They will also structure our ethical response in section V.

\section{The greenhouse effect: scientific issues}

The scientific evidence for the greenhouse effect, and the basis of predictions about its longer term consequences, are complex. Here we can only briefly rehearse the main issues. ${ }^{23}$

There is now no doubt that the global climate has experienced a warming of about $0.5^{\circ} \mathrm{C}$ since about 1860 . Sufficient evidence has now accumulated that scientists are able to discount measurement error, or short run fluctuations, as explanations for what has been observed. The evidence is equally strong that carbon dioxide concentrations in the atmosphere have increased by about $25 \%$ over the same period. Furthermore, since the 1930s, the increase of carbon dioxide concentrations has followed an exponential growth path, and this has been reinforced more recently by evidence for similar growth paths for concentrations of other greenhouse gases.

The long term significance of carbon dioxide concentrations has been made absolutely clear from the analysis of ice cores from Antarctica. The Vostok ice cave gives evidence of climatic conditions going back over 160,000 years. There is extremely close correlation between movements in temperature, and the atmospheric concentration of carbon dioxide and methane, which can be determined from the analysis of bubbles of air trapped in the ice as it formed year by year through snowfall. An even more dramatic comparison can be made between the planets Venus and Mars. Venus has an atmosphere rich in $\mathrm{CO}_{2}$, and a surface temperature exceeding $400^{\circ} \mathrm{C}$ : Mars has very little $\mathrm{CO}_{2}$, and temperatures about $-50^{\circ} \mathrm{C}$. Carbon

\footnotetext{
${ }^{23}$ For excellent recent surveys see S.H. Schneider, op. cit., R.A. Houghton and G.M. Woodwell, 'Global climatic change', Scientific American, 260.4 (April 1989) 18-26, T.H. Graedel and P.J. Crutzen 'The changing atmosphere', and S.H. Schneider 'The changing climate', Scientific American, 261.3 (September 1989) in a special issue entitled Managing Planet Earth, with many interesting articles, and Royal Society, The greenhouse effect: the scientific basis for policy, (A submission to the House of Lords Select Committee, Royal Society, July 1989). For a more popular exposition, but well researched see F. Pearce, Turning Up the Heat, ( London, Bodley Head, 1989).
} 
dioxide traps radiant heat from the surface of the earth: the surface is heated by the sun, but the heat cannot escape.

Ignoring production of carbon dioxide by the burning of fossil fuels, there are three natural cycles of carbon between the atmosphere and the surface of the globe. The first is a geochemical carbon cycle. ${ }^{24}$ Carbon dioxide is absorbed from the atmosphere in the process of weathering of carbonate and silicate rocks. It is released back into the atmosphere via volcanic and tectonic activity. These processes are naturally quite slow acting, and it is not obvious that, for example, an increase in carbon dioxide in the atmosphere would increase the rate of weathering to any substantial degree. The second mechanism is via the oceans. Atmospheric carbon dioxide is absorbed by the oceans at a rate which depends on the levels of concentration of carbon dioxide in the atmosphere. At least some of that carbon dioxide is fixed in the shells of marine organisms as calcium carbonate, and is deposited on the sea bed when those organisms die. This then joins the first geochemical cycle. The third mechanism is the biological cycle. Carbon dioxide is taken from the atmosphere by photosynthesis in vegetation. Some of this is respired directly at night. The rest is returned to the atmosphere more slowly by the process of decay of organic matter in the soil.

One of the key questions is how much these natural mechanisms could cope with an increase in atmospheric carbon dioxide occasioned by the burning of fossil fuels. A fairly rapid adjustment is needed, and that probably points to the third, biological, mechanism. An increase in atmospheric carbon dioxide, coupled with increased warmth, stimulates more rapid growth in vegetation by increased photosynthesis. However, it seems probable that it will not speed up as quickly as the offsetting mechanism of decay of organic matter. So the net effect could be, initially at least, that carbon dioxide concentrations in the atmosphere increase. The effect could be much worse, if the increase in atmospheric carbon dioxide is compounded by the destruction of forests, particularly rain forests in the tropics. Two thirds of of the remaining rain forests are in the

${ }^{24}$ R.A. Berner and A.C. Lasaga, 'Modelling the Geochemical Carbon Cycle' Scientific American 260.3 (March 1989) 54-61. 
Amazon basin, and their great importance for world climate has been recognised for some time. ${ }^{25}$ Yet there is extensive evidence to show that large areas of the forest have been cleared in recent years for cattle ranching, particularly in the states of Mato Grosso, Rondonia and Acre. Such clearings in fact only provide grazing for three or four years, but the disturbance of the soil and vegetation cover is such that forest regeneration does not occur (as it does in abandoned clearings from peasant agriculture).

The rain forests may also have a significant role in generating cloud cover. The hypothesis is that forests produce bacteria and other organic matter which is taken up into the atmosphere by evapotranspiration. The bacteria then form the nuclei of water droplets which become clouds. This is an example of a Gaian hypothesis of feedbacks in the biosphere. Higher temperatures increase evapotranspiration, giving more cloud cover, and hence cutting out some of the warming effect of the sun. A similar hypothesis involves the action of algae in the oceans giving off dimethyl sulphide, which is also thought to be significant in cloud formation. One suggestion is that warmer conditions encourage the growth of algae, with the feedback mechanism of more clouds to cut out the sun.

To sum up, the concern is that human activities are releasing carbon dioxide on such a scale that the geochemical and biological mechanisms cannot cope. By deforestation we are in fact decreasing the effectiveness of the biological mechanisms. The problem is compounded by the accumulation of other greenhouse gases in the atmosphere, such as methane, chlorofluorocarbons (CFCs) and nitrous oxides. Methane is generated by farming (especially cattle, and rice paddy fields) and by the decomposition of rubbish. There is another potentially major source of methane in the tundra: if these frozen bogs were to thaw out with global warming, methane would be released in large quantities. CFCs have been used extensively in refrigerators and aerosols. Nitrous oxides are produced from car exhausts. These greenhouses gases are much more effective at trapping radiation than carbon dioxide. The best estimate is

${ }^{25}$ R.E. Dickinson (ed.). The Geophysiology of Amazonia, (New York, Wiley, 1987). 
that these now contribute as much to global warming as carbon dioxide.

Projecting the effects of the greenhouse gases is a very imprecise science. ${ }^{26}$ A first stage is to make estimates of the emissions of greenhouse gases, which depend on the rate at which fossil fuels are consumed, and on economic activity generally. The second stage is to estimate the capacity of the feedback mechanisms to absorb additional carbon dioxide: our knowledge of these individual mechanisms is very incomplete, and we have not yet been able to assess how they add up. However the evidence of increasing carbon dioxide concentrations in the atmosphere over the last hundred years suggests that they will be able to absorb only a part of additional carbon dioxide emissions from the burning of fossil fuels. The third stage is to estimate the global climatic response. The best predictions of the global climatic models are that if atmospheric carbon dioxide concentrations double (as seems likely sometime in the next century) then surface temperatures will rise between $3.5^{\circ}$ and $5^{\circ} \mathrm{C}$. The uncertain factors are the effects on the reflectiveness of the biosphere to incoming radiation from the sun. Increased cloud cover could act to cool things down. Retreating ice caps would make the earth less reflective and push temperatures up.

The fourth stage is to predict regional climatic changes arising from a general warming. All the evidence suggests a far from uniform effect. The interiors of the continents are likely to get much hotter and drier than those regions near to the oceans. ${ }_{\text {Broecker }}{ }^{27}$ has warned that we may be wrong to presume that these regional changes will be gradual: he believes that quite sudden and rapid change could be precipitated by changes in the deep water flow in the oceans. Given all these uncertainties, it is probably futile to speculate about specific impacts on human activities. However it would be foolish not to expect major impacts on agriculture, on land water supplies and on the sea level. Only the last would have a uniform effect: the sea level will rise by up to 1.5 metres, if the West Antarctic sheet

265.H. Schneider op. cit.

${ }^{27}$ W.S. Broecker op. cit. 
does not break up. If it should break up, then a rise of four to five metres is predicted.

\section{What should be done about the greenhouse effect?}

If the scientists are right, we are heading for a global catastrophe, and we need to ask why. One simple answer is that we have been ignorant of the effects that human activity has on the environment. However it is doubtful whether better and more widely disseminated information would be sufficient to overcome the problem. The reason is that the greenhouse effect is the cumulative impact of a multitude of individual activities in all parts of the world. The key feature of such activities is that they are decentralised. No individual can know precisely his or her contribution to the global total of greenhouse gases.

This problem has long been recognised in economic analysis as the problem of the commons. If a community has common pasture on which individuals can graze their animals, then there is a tendency for overgrazing to occur. The reason is simple: each individual considers only the returns to an additional animal that he puts on the common. He takes no note of the impact on the whole common. Indeed the impact of one additional animal may be truly negligible; it is when several hundred of his neighbours do the same that difficulties arise. In recent years, such analysis has been successfully applied to problems concerning sea fisheries and whales. The same analysis can be applied to the atmosphere. It is a global common, which provides chemical 'sinks' to absorb and destroy greenhouse gases. But the capacity is limited: if the biosphere is overloaded, then the greenhouse gases begin to accumulate. However even if the individual knows that there are such limits, he or she has no incentive to hold back. Because each personal contribution to the problem is negligible, so the total improvement from refraining is negligible. Everyone is tempted to rely on the self-denial of others. 
There are two other economic factors involved in the greenhouse effect and both are fairly technical. ${ }^{28}$ The first is the level of discount rates. Consider a biological resource that grows or is renewed at a rate of two per cent per annum, but that real interest rates in financial markets are five per cent. Then it will be profitable to deplete the stock now, and invest the financial return, rather than leave the stock to grow. A typical example is that of forest resources. Given that trees grow slowly, on purely financial criteria it is better to cut down the stock now rather than leave them to grow for another year: and replanting is probably not an economic proposition, since returns are so far in the future. It is precisely considerations of this kind that have led to destruction of tropical rain forests, and carelessness about regeneration in the longer term. The second problem is that future generations do not have a vote in current markets, so that they cannot make 'bids' for resources to be conserved for future use. A partial mechanism is the altruism of the current generation in leaving resources for our dependents. But it is far from obvious that we do this (aggregating all the decisions of individuals) to an appropriate degree. In any case, we are ignorant about the future consequences of our actions: about the impact of pollution in the long run, and about the alternative and vital future uses of exhaustible resources which we are now using up (the loss of plant species in Amazonia is a good example).

If we now apply the Christian derivative principles outlined in section III above, it is evident that we should be very concerned about the greenhouse effect. First, we need to acknowledge that the created order has value in and of itself: it is not just a resource to be exploited. Second, we need to guard against destruction or destabilisation of that order through our economic activities. Mankind should live within the parameters of a long run sustainable created order, using resources (especially common resources like the atmosphere) only at the rate at which they can be biologically (or naturally) renewed.

\footnotetext{
${ }^{28}$ See, for example, J.M. Hartwick and N.D. Olewiler The Economics of natural resource use, (New York, Harper and Row, 1986) and P.S. Dasgupta and G.M. Heal Economic Theory and Exhaustible Resources (CUP, 1979).
} 
On this basis it is important to examine some of the solutions for the problems previously identified. ${ }^{29}$ The classic solution to the problem of the commons is to create private property rights in the natural resource. Then all the problems of overutilisation rebound to the individual, and are not imposed on other users. In the case of the atmosphere, this kind of proposal is self-evidently nonsense. It is a global resource, and there is no way to create property rights. The alternative is some form of rationing: a 'safe' level of emissions is determined, and then rationed out by use of a tax mechanism or direct controls. The issue of discount rates and future generations is more difficult to solve. It is hard to see how an allocation of property rights, or a tax system is going to be effective. For example, if we create private property rights in a resource with a very slow rate of biological renewal, the private owners may simply decide to maximise their own personal incomes by running down the stock of the resource without regard to the long term consequences. Such an attitude has been aptly summarised by the adage: 'Why should we do anything for future generations; they don't do anything for us'!

The reasons why Christians should be uncomfortable with these proposals are not difficult to isolate. The criteria which are applied are broadly utilitarian, and correctives for market failures are designed to maximise over time the stream of benefits accruing to the human race. One such proposal is that we should aim to hand on to future generations a combined stock of natural resources and physical capital which is no smaller than the one we have inherited. ${ }^{30}$ What is missing is any sense that the natural order has value of itself, quite apart from the uses that man may have for it either now or in the future. Furthermore, the utilitarian criterion falls down precisely on the basis of our ignorance: it is difficult to apply a cost/benefit analysis to future consequences which are completely unknown.

Christians would require that policy should be motivated by a conservation objective. The preservation of the created order is good in itself: the onus is on those who use a re-

${ }^{29}$ For more detailed analysis, see D.A. Hays op. cit. ch 6 \# 3-6.

${ }^{30}$ D. Pearce, Blueprint for a Green Economy, (London, Earthscan, 1989). 
source to prove that long run environmental sustainability is not impaired. The implementation of such policies for greenhouse gases is not going to be easy. First, there would have to be international agreement as to the levels of carbon dioxide and other emissions that are sustainable by the atmosphere. These agreements would then have to decide on quota allocations between different nations. ${ }^{31}$ Even if these could be agreed, the problem of verification is extremely difficult. It would always be in the interests of one nation to renege on its obligations, if it could be undetected. Given the number of parties to any such agreement, the problem of the global commons reasserts itself with the players as nations rather than as individuals. Second, there would have to be a mixture of taxes and regulations to ration the national quota to users within each economy. All this would be much easier, if there was a genuine consensus that conservation was a priority for national life, so that compliance was voluntary rather than enforced.

\section{Unresolved issues}

This paper should be read as an invitation to start exploring what is undoubtedly a serious issue for the future of mankind within a specifically Biblical ethical framework. On a scale of concern about environmental issues, we have argued for a very 'Green' position as appropriate for Christians. The problems of implementation - even to achieve some sort of secondbest solution-are likely to be extremely daunting. Besides there is much interdisciplinary thinking still to be done on virtually every aspect of the problem discussed above. It is therefore appropriate to conclude with some unresolved issues:

(i) are there significant contributions from the Biblical themes of redemption, and of the Last Things, that should inform our discussion of these issues? ${ }^{32}$ What are we to make of

\footnotetext{
${ }^{31}$ For comparison, the events leading to the 1987 Montreal Protocol for protection of the ozone layer are instructive. For a popular account see J. Gribbin, The Hole in the Sky, (London, Corgi, 1988).

${ }^{32} \mathrm{~W}$. Granberg-Michelson op. cit. argues that there are.
} 
Romans 8:19, Isaiah 66 or even the apocalyptic of Revelation 8 and $9 ?^{33}$

(ii) how can we live our lives in the face of uncertainty about the consequences of our actions for the environment? Even if we seek to be faithful to the ethical injunction to take care of the earth, we have to accept our human frailty and fallibility.

(iii) how can we define the limits of acceptable impacts on the environment? The anticipated greenhouse effect is within the range of variation of the earth's climate in the last 160,000 years. Is it the current climate which should be preserved?

(iv) how can we resolve the apparent conflict between preserving the environment and economic well being? Being 'green' may be all very well for the middle classes and the rich: but what about the needs of the poor, especially in the Third World? International redistribution may be a necessary complement to any policy to save us from the greenhouse effect.

${ }^{33}$ In Tyn. B. 41.2 (November, 1990) Dr. F. W. Bridger will deal with the implictions of VI. (i ) in his article-'Ecology and Eschatology'. 